\title{
Examination of a Fabricated Impedance Meter by Analysing the Electrical Properties of $\mathrm{Ni}_{0.65} \mathrm{Zn}_{0.35} \mathrm{Fe}_{2} \mathrm{O}_{4}$ (Ferro-Magnetic) Material
}

\author{
P. Kanaka Raju, C. Kavitha, C. Mani Kumar, D. Rama Krishna
}

\begin{abstract}
Impedance (Z) may be defined as the total opposition by a component (or electronic material) that offers to the AC (alternating current) at an applied signal frequency, parameters of impedance are utilized to analyze materials/electronic components characteristics. Impedance/LCR measuring instrumentation are costly or either do not enough accuracy and may have limited frequency range. There are many impedance measurement methods, each of which has their own pros and cons. While considering factors like frequency range, measurement band width, accuracy in measurement and its ease of operation, there is no single impedance measurement instrument that includes all these parameters. This research article describes a handy/portable impedance meter that depends on auto balancing bridge technique, which is capable of making impedance parameter measurements up to $20 \mathrm{Mhz}$ frequency. An analog frequency generator was made up of max038 (IC) which stimulates the impedance measurement circuit that was composed of reference and also the impedances that are unknown. The applied frequency through the impedances (electronic materials) and their electronic parametrics like inseries inductance $\left(L_{s}\right)$, inparallel capacitance $\left(C_{p}\right)$ and inseries resistance $\left(R_{s}\right)$ along with some sub-parameters were first digitalized and then displays. The fabricated impedance meter's performance was analysed by correlating the results obtained by it, with the results of a commercially available impedance instrument-the Newton $4^{\text {th }}$ limited, NumetriQ, Model no. PSM-1735, for different composite electronic materials, some of them are multi-ferrites, ferroelectric and ferro-magnetic, materials. For every material, the error percentage was analysed; which is less than $3 \%$ was observed. In this paper, $\mathrm{Ni}_{0.65} \mathrm{Zn}_{0.35} \mathrm{Fe}_{2} \mathrm{O}_{4}$-Ferro-magnetic material's both thermal properties and electrical properties were analysed by fabricated and by the commercial instruments. Results are tabulated and then graphs are plotted.
\end{abstract}

Keywords : Impedance measurement, Frequency source, Auto balancing bridge, $\mathrm{Ni}_{0.65} \mathrm{Zn}_{0.35} \mathrm{Fe}_{2} \mathrm{O}_{4}$, Performance analysis, Percentage of error.

Revised Manuscript Received on December 13, 2019.

* Correspondence Author

P. Kanaka Raju*, Department of Electronics and Physics, Institute of Science, GITAM (Deemed to be University), Visakhapatnam, Andhra Pradesh, INDIA 530045. Email: kanakaraju.pappala@gitam.edu

C. Kavitha, Department of Electronics and Physics, Institute of Science, GITAM (Deemed to be University), Visakhapatnam, Andhra Pradesh, INDIA 530045 .

C. Mani Kumar, Department of Electronics and Physics, Institute of Science, GITAM (Deemed to be University), Visakhapatnam, Andhra Pradesh, INDIA 530045

D. Rama Krishna ${ }^{\#}$, Department of CSE, Institute of Technology, GITAM (Deemed to be University), Visakhapatnam, Andhra Pradesh, INDIA 530045.

\section{INTRODUCTION}

Impedance meter is an electrical/electronic test equipment used for the measurement of electronic parameters like inductance (L), capacitance (C) and resistance ( $\mathrm{R}$ ) of an electric circuit or component. Resistance is defined as its opposition to the flow of current. Capacitance is defined as the quantity of electrical energy stored at an electric potential, Inductance causes a potential difference, which is directly proportion to changes in rate of current in an electric circuit [14]. All these electrical parameters are not measured directly. But are determined from the impedance measurements [1]. The parameter -impedance is useful to find the characteristics of materials. Impedance can be written as $\mathrm{Z}=\mathrm{R}+\mathrm{jX}$ in rectangular co-ordinates, reciprocal of impedance mathematically defined as, $1 / Z=1 /[R+j X]$ or $Y=(G+j B)$, here $Y-$ admittance, $G-$ conductivity, $B-$ susceptance and $\mathrm{X}$ - represents reactance. Unit of impedance is $\mathrm{Ohm}(\Omega)$ and the unit of admittance is Siemen (S). Impedance parameter represents $\mathrm{R}$ - the series resistance and the reactance $-\mathrm{X}$ as a sum of $\mathrm{R}$ and $\mathrm{X}$. Impedance was admittance when connected in parallel. Two forms of reactances: $X_{L}$ (inductive) and $X_{C}$ (capacitive), here $X_{L}=$ $2 \pi \mathrm{fL} \& \mathrm{X}_{\mathrm{C}}=1 /(2 \pi \mathrm{fC}), \mathrm{f}$ is the frequency applied.

Typically, instruments for impedance measurement, were either expensive or poor in accuracy and may be with narrow range in frequency. Newton 4th limited and Agilent technologies the leading manufacturers for the design of measurement systems, which covers the frequency range from few hertz up to few megahertz with basic accuracy. However, their cost is of nearly hundreds of \$ (dollars), which is beyond the budget of some institutes and organizations for research [16]. Therefore, demand increases to low cost, precise and for portable systems, capable of performs impedance measurement at broad frequencies, still with the accuracy comparable to that with superior measurement equipment of impedance [3].

In this paper, impedance meter was developed based on auto balancing technique, then fabricated and its working functionality is analyzed by testing the electrical properties of different materials. Results were evaluated and then graphs are plotted. 


\section{Examination of a Fabricated Impedance Meter by Analysing the Electrical Properties of $\mathrm{Ni}_{0.65} \mathrm{Zn}_{0.35} \mathrm{Fe}_{2} \mathrm{O}_{4}$ (Ferro-Magnetic) Material}

\section{METHODS AND METHODOLOGY}

Many methods of measurement are applicable for impedance [6], each one having strengths and limitations. By considering these measuring factors such as measuring range of the instrument, its frequency coverage, easiness in operation (auto/ manual) and its measurement accuracy. For measurement, no single method or instrument to include all these parameters [4]. Auto-balancing bridge is the common useful method in medium frequency range of impedance measurement instruments [8], with operating frequency range up to 45 megahertz. The balanced bridge maintain the Lp (lower-potential) lead at 0 voltage. The pros of measurement of impedance of a DUT (device under testing) are: i) ammeter input impedance is at virtual ground hence the measurements does not affected, ii) distributive capacitance of testing cables does not affects the impedance measurements. Since no voltage is present between the inner and outer shield conductors. iii) in order to remove the stray capacitance effects, guarding techniques were incorporated to the instrument [9].

For the measurement of impedance, at first the potential difference across the DUT \& the current passes through it can be identified. The input voltage of the device is determined by high potential $(\mathrm{Hp})$ lead. The Hp lead is separated from high current $(\mathrm{Hc})$ lead, is the output terminal [5]. Isolation is useful in accurate determination of voltage across an unknown device. The current passes in the DUT appears at low-current (Lc) lead, there exists a certain potential at Lc lead, the stray capacitance at cable terminals and at ground was generated due to may be the current flews to GND (ground) [15]. To minimise this leakage, Lp lead was kept at the GND level known as 'virtual GND' level, it dependents on null-loop known as feedback loop. The measurement path is from the voltage or current measuring circuit in the impedance measurement system to the externally connected DUT. Figure 1(a) shows the configuration of a four-terminal pair (4TP) cable, it eliminates both stray capacitance at the test leads as well as mutually induced inductance of testing wires and also eliminates the inseries residual impedance of test cables [5]. 4TP cable configuration helps to measure impedances from low range $\mathrm{Z}$ to high range [2]. The fabricated impedance meter was embedded with a DC (direct current) bias, it can be useful for either in source of current or a source of voltage [7].

(a)

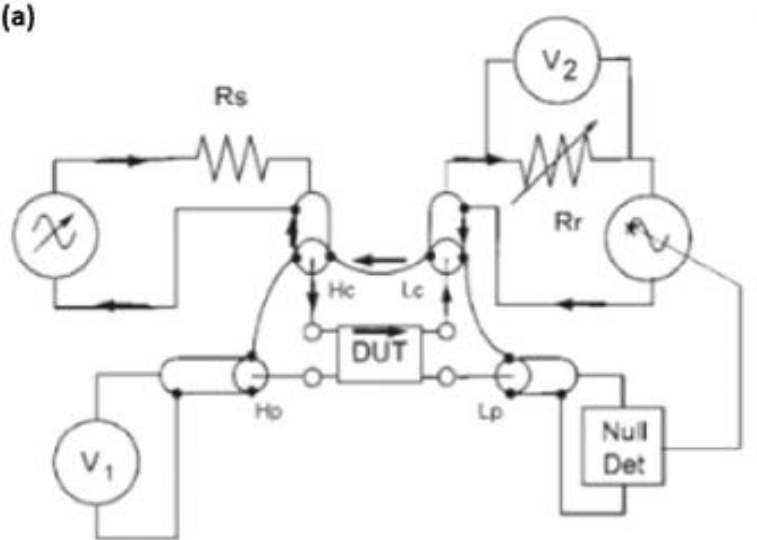

Fig. 1(a). Auto-Balancing-Bridge with 4TP configuration

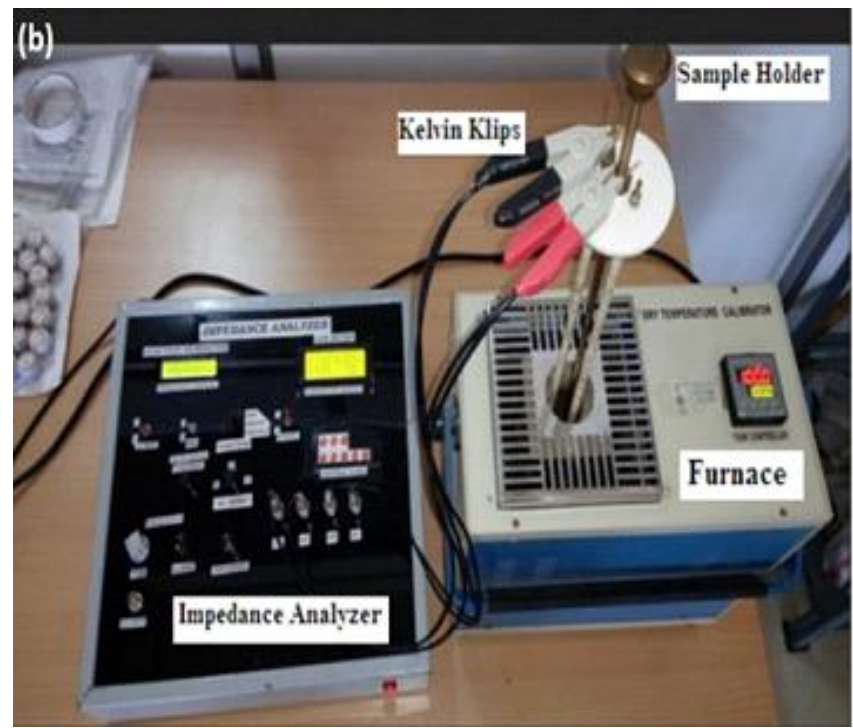

Fig. 1(b). Fabricated impedance meter setup

\section{FABRICATED IMPEDANCE METER}

Figure 1(b) shows the complete setup of an impedance meter constructed over a PCB (printed circuit board) with some main electronic components such as TL08XX- an op-amp., CD405X-CMOS eight channel analog Multiplexer and De multiplexer, OP07 an ultra-low offset op-amp., and STC12C5A60S2- advanced 8-bit microcontroller. This instrument is compactly designed on metal casing as shown in figure 1(b). It measures the capacitance (C), inductance (L) and resistance $(\mathrm{R})$ of an unknown electronic component or of a material with some other parameters like Dissipating factor-D, Quality factor-Q, Phase angle- $\theta$ and effective inseries resistance-(ESR) at different applied frequencies over a range of bias magnitude [1]. This instrument's functionality was governed by an advanced microcontroller operates the peripherals like keyboard and display unit and it also handles the interface circuitry [3]. It was intelligent by formalism to sets up the proper conditions for proper measurement of material/component parameters and also performs calculations for finding the sub-parameter values. In general, best results were obtained by the usage of kelvin clips. Thus, those are incorporated for the measurement of large and or unusual sized components, and the clips can handle the components up to 0.3 " (or $7.6 \mathrm{~mm}$ ) in diameter. Measuring accuracy will depends on: how accurate the applied signal frequency?, input signal magnitude, rate of measurements and finally, the impedance of unknown device might be within the measurement range of the instrument. All accuracy parameters are analyzed from the impedance graphs or from their individual parametric graphs only. Based on these graphs/plots, its optimal range and the instrument's measurement accuracy can be evaluated. The fabricated impedance meter having the following feature/specifications: tolerance is up to $5 \%$, auto calibration, auto range adjustment, automatic test mode, the bias signal frequency range is 1 hertz to 17 megahertz; $\mathrm{C}-(0.1 \mathrm{pF}-$ $10000 \mu \mathrm{F}), \mathrm{L}-(0.01 \mu \mathrm{H}-1000 \mathrm{H})$ and $\mathrm{R}-(0.01 \Omega-9.999$ Mega $\Omega$ ). 


\section{PERFORMANCE ANALYSIS}

This research article describes the development, fabrication and performance evaluation of a portable and low-cost instrument, with the capability of impedance measurements at frequencies up to 17 megahertz, is governed by a microcontroller controls entire hardware of the entire circuit. The microcontroller was run by a software/ an algorithm which is needed for the operation of the instrument for measurement of the impedances [3]. The present article also dealing with the analysis of the fabricated impedance meter by comparing and then correlating the obtained readings with the results of a commercially available impedance equipment - Newton $4^{\text {th }}$ limited NumetriQ, model no. PSM1735 [12], for various composite electronic materials like mutli-ferrite materials, ferro-electric and ferro-magnetic materials [10]. Commercial equipment had a number of measuring functions over 40 megahertz frequency. Table-I describes the comparison between the commercial and the fabricated impedance measurement instruments.

Table- I: Specifications of commercial verses fabricated impedance meter

\begin{tabular}{|c|c|c|}
\hline Parameter & Commercial & Designed \\
\hline Signal source & $\begin{array}{l}\text { Direct Digital Synthesis } \\
\text { (DDS) }\end{array}$ & $\begin{array}{l}\text { Analog (based on } \\
\text { MAX038) }\end{array}$ \\
\hline Frequency range & Up to $45 \mathrm{Mhz}$ & up to $15 \mathrm{Mhz}$ \\
\hline Amplitude & $10 \mathrm{Vpp}$ & $4.5 \mathrm{Vpp}$ \\
\hline $\begin{array}{l}\text { Frequency and } \\
\text { Amplitude control by }\end{array}$ & DDS (12 bit DAC) & Potentiometer \\
\hline Accuracy & $\begin{array}{l}\text { Frequency: }+/-0.05 \% \\
\text { Amplitude: }+/-5 \%\end{array}$ & $\begin{array}{l}\text { Frequency: }+/-0.1 \% \\
\text { Amplitude: }+/-2 \%\end{array}$ \\
\hline Type of measurement & DFT analysis & DFT analysis \\
\hline $\begin{array}{l}\text { Electrical } \\
\text { measurements }\end{array}$ & $\begin{array}{l}\mathrm{R}, \mathrm{L}, \mathrm{C}(\mathrm{AC}), \mathrm{Q}, \text { phase, } \\
\tan \delta, \text {, circuits of series } \\
\text { and/or parallel }\end{array}$ & $\begin{array}{l}\mathrm{L}, \mathrm{C}, \mathrm{R}, \mathrm{D}, \mathrm{Q} \text { and } \\
\text { ESR circuits series } \\
\text { and/or parallel }\end{array}$ \\
\hline Functionality & Automatic and Manual & Manual \\
\hline Type of display & $\begin{array}{l}\text { Numerical display and } \\
\text { graph of any } \\
\text { measurement }\end{array}$ & Numeric values \\
\hline Ranges of $\mathrm{C}, \mathrm{L}$ and $\mathrm{R}$ & $\begin{array}{l}100 \mathrm{pF} \text { to } 100 \mathrm{uF} \\
1 \mu \mathrm{H} \text { to } 100 \mathrm{H} \\
1 \Omega \text { to } 100 \mathrm{M} \Omega\end{array}$ & $\begin{array}{l}0.1 \mathrm{pF}-9999 \mu \mathrm{F} \\
0.01 \mu \mathrm{H}-999 \mathrm{H} \\
0.0002-19999 \mathrm{~K} \Omega\end{array}$ \\
\hline
\end{tabular}

In this research article, we considered $\mathrm{Ni}_{0.65} \mathrm{Zn}_{0.35} \mathrm{Fe}_{2} \mathrm{O}_{4}$ - a ferro-magnetic material [11] for evaluation of the fabricated impedance meter. The properties of both electronic as well as thermal were analyzed then graphs were plotted of the obtained results. Evaluation of instrument was done in two phases [10]. i). By changing signal frequency at room temperature approximately $31^{\circ} \mathrm{C}$, and ii). By changing the furnace temperature at a fixed signal frequency.

\section{RESULTS AND DISCUSSION}

Phase-i, studies are functions of change of signal frequency at approximately at $31^{\circ} \mathrm{C}$ (room temperature). Phase-ii studies as a function of temperature of the furnace (where the DUT is at sample holder) at fixed bias frequency (at 1Kilo hertz). In these two phases, electronic parameters of the material like inseries resistance -Rs, inparallel capacitance $-\mathrm{Cp}$ and inseries inductance -Ls were measured by the commercial one and with the fabricated meter. Figure 2 depicts $\mathrm{Ni}_{0.65} \mathrm{Zn}_{0.35} \mathrm{Fe}_{2} \mathrm{O}_{4}$ is a ferro-magnetic pellet with $10 \mathrm{~mm}$ in diameter and $0.65 \mathrm{~mm}$ in thickness was considered for evaluation of fabricated impedance meter $[10,13,16]$.

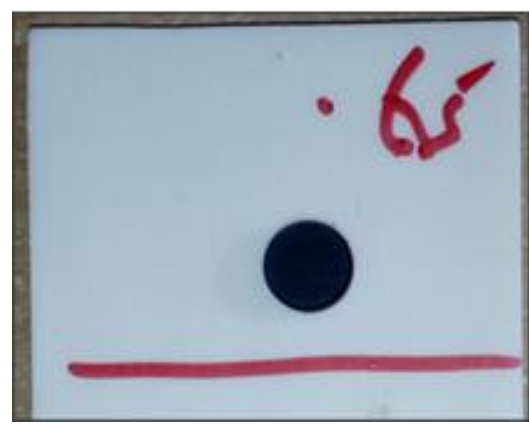

Fig. 2. $\mathrm{Ni}_{0.65} \mathrm{Zn}_{0.35} \mathrm{Fe}_{2} \mathrm{O}_{4}$ (ferro-magnetic) pellet of $0.65 \mathrm{~mm}$ thickness with $10 \mathrm{~mm}$ diameter

In table- II, the inseries inductor- Ls, inparallel capacitor$\mathrm{Cp}$ and inseries resistor- Rs values of commercial vs (verses) fabricated instruments were tabulated at many signal frequencies of $\mathrm{Ni}_{0.65} \mathrm{Zn}_{0.35} \mathrm{Fe}_{2} \mathrm{O}_{4}$ material at temperature of a room of approximately $31^{\circ} \mathrm{C}$ and those results were plotted as graphs for comparison and correlation purpose as shown in figures $3 \mathrm{a}, 3 \mathrm{~b}$ and $3 \mathrm{c}$. In table- III, the inseries inductor Ls, inparallel capacitor $\mathrm{Cp}$ and inseries resistor Rs values of commercial vs fabricated instruments were tabulated against variable furnace temperature of $\mathrm{Ni}_{0.65} \mathrm{Zn}_{0.35} \mathrm{Fe}_{2} \mathrm{O}_{4}$ material at $1 \mathrm{KHz}$ frequency, those results were plotted as graphs for comparison and correlation purpose as shown in figures $4 \mathrm{a}$, $4 \mathrm{~b}$ and $4 \mathrm{c}$.

Table- II Comparison of $\mathrm{Ni}_{0.65} \mathrm{Zn}_{0.35} \mathrm{Fe}_{2} \mathrm{O}_{4}$ material at Room Temperature

\begin{tabular}{|c|c|c|c|c|c|c|}
\hline \multicolumn{7}{|c|}{$\mathrm{Ni}_{0.65} \mathrm{Zn}_{0.35} \mathrm{Fe}_{2} \mathrm{O}_{4}$ (at room temperature $\left.\approx 31^{\circ} \mathrm{C}\right)$} \\
\hline \multirow{2}{*}{$\begin{array}{l}\text { Freque } \\
\text { ncy }\end{array}$} & \multicolumn{3}{|c|}{$\begin{array}{l}\text { Commercial Instrument } \\
\text { Results }\end{array}$} & \multicolumn{3}{|c|}{$\begin{array}{l}\text { Fabricated Instrument } \\
\text { Results }\end{array}$} \\
\hline & $\begin{array}{l}\text { Ls } \\
\text { (Henry) }\end{array}$ & $\begin{array}{l}\text { Cp } \\
\text { (Farad } \\
\text { s) }\end{array}$ & $\begin{array}{l}\text { Rs } \\
(\text { Ohms })\end{array}$ & $\begin{array}{l}\text { Ls } \\
\text { (Henry }\end{array}$ & $\begin{array}{l}\text { Cp } \\
\text { (Farad } \\
\text { s) } \\
\end{array}$ & $\begin{array}{l}\text { Rs } \\
(\mathrm{Ohms} \\
\end{array}$ \\
\hline $\begin{array}{l}1.00 \mathrm{E}+ \\
02\end{array}$ & $\begin{array}{l}-7.57 \mathrm{E}+ \\
03\end{array}$ & $\begin{array}{l}4.3823 \\
\mathrm{E}-10\end{array}$ & $\begin{array}{l}5.80 \mathrm{E}+0 \\
5\end{array}$ & $\begin{array}{l}-7.07 \mathrm{E} \\
+03\end{array}$ & $\begin{array}{l}3.53 \mathrm{E}- \\
10\end{array}$ & $\begin{array}{l}5.73 \mathrm{E}+ \\
05\end{array}$ \\
\hline $\begin{array}{l}5.00 \mathrm{E}+ \\
02\end{array}$ & $\begin{array}{l}-2.41 \mathrm{E}+ \\
02\end{array}$ & \begin{tabular}{|l|}
3.7276 \\
E-10
\end{tabular} & $\begin{array}{l}2.70 \mathrm{E}+0 \\
5\end{array}$ & $\begin{array}{l}-3.11 \mathrm{E} \\
+02\end{array}$ & $\begin{array}{l}3.23 \mathrm{E}- \\
10\end{array}$ & $\begin{array}{l}8.86 \mathrm{E}+ \\
04\end{array}$ \\
\hline $\begin{array}{l}1.00 \mathrm{E}+ \\
03\end{array}$ & $\begin{array}{l}-6.76 E+ \\
01\end{array}$ & \begin{tabular}{|l|}
3.5473 \\
E-10
\end{tabular} & $\begin{array}{l}1.00 E+0 \\
5\end{array}$ & $\begin{array}{l}-8.07 \mathrm{E} \\
+01\end{array}$ & $\begin{array}{l}3.12 \mathrm{E}- \\
10\end{array}$ & $\begin{array}{l}4.19 \mathrm{E}+ \\
04\end{array}$ \\
\hline $\begin{array}{l}1.00 \mathrm{E}+ \\
04\end{array}$ & \begin{tabular}{|l}
$-8.13 E-0$ \\
1
\end{tabular} & \begin{tabular}{|l|}
3.0799 \\
E-10
\end{tabular} & $\begin{array}{l}5.36 E+0 \\
3\end{array}$ & $\begin{array}{l}-8.99 \mathrm{E}- \\
01\end{array}$ & $\begin{array}{l}2.80 \mathrm{E}- \\
10\end{array}$ & $\begin{array}{l}4.01 \mathrm{E}+ \\
03\end{array}$ \\
\hline $\begin{array}{l}1.00 \mathrm{E}+ \\
05\end{array}$ & $\begin{array}{l}-9.26 \mathrm{E}-0 \\
3\end{array}$ & $\begin{array}{l}2.7191 \\
\text { E-10 }\end{array}$ & $\begin{array}{l}4.67 \mathrm{E}+0 \\
2\end{array}$ & $\begin{array}{l}-9.92 \mathrm{E}- \\
03\end{array}$ & $\begin{array}{l}2.54 \mathrm{E}- \\
10\end{array}$ & $\begin{array}{l}3.92 \mathrm{E}+ \\
02\end{array}$ \\
\hline $\begin{array}{l}1.00 \mathrm{E}+ \\
06\end{array}$ & $\begin{array}{l}-1.03 E-0 \\
4\end{array}$ & $\begin{array}{l}2.4419 \\
\text { E-10 }\end{array}$ & $\begin{array}{l}4.14 E+0 \\
1\end{array}$ & $\begin{array}{l}-1.08 \mathrm{E}- \\
04\end{array}$ & $\begin{array}{l}2.33 E- \\
10\end{array}$ & $\begin{array}{l}3.83 \mathrm{E}+ \\
01\end{array}$ \\
\hline $\begin{array}{l}1.00 \mathrm{E}+ \\
07\end{array}$ & $\begin{array}{l}-1.68 \mathrm{E}-0 \\
6\end{array}$ & $\begin{array}{l}1.5014 \\
\text { E-10 }\end{array}$ & $\begin{array}{l}5.08 E+0 \\
0\end{array}$ & $\begin{array}{l}-1.72 \mathrm{E}- \\
06\end{array}$ & $\begin{array}{l}1.46 \mathrm{E}- \\
10\end{array}$ & $\begin{array}{l}8.79 \mathrm{E}+ \\
00\end{array}$ \\
\hline $\begin{array}{l}1.50 \mathrm{E}+ \\
07\end{array}$ & $\begin{array}{l}-1.52 \mathrm{E}-0 \\
6\end{array}$ & \begin{tabular}{|l|}
6.5153 \\
E-11
\end{tabular} & \begin{tabular}{|l}
$-5.32 \mathrm{E}+$ \\
01
\end{tabular} & $\begin{array}{l}-2.42 \mathrm{E}- \\
06\end{array}$ & $\begin{array}{l}3.15 \mathrm{E}- \\
11\end{array}$ & $\begin{array}{l}-1.57 \mathrm{E} \\
+02\end{array}$ \\
\hline
\end{tabular}


Examination of a Fabricated Impedance Meter by Analysing the Electrical Properties of $\mathrm{Ni}_{0.65} \mathrm{Zn}_{0.35} \mathrm{Fe}_{2} \mathrm{O}_{4}$ (Ferro-Magnetic) Material

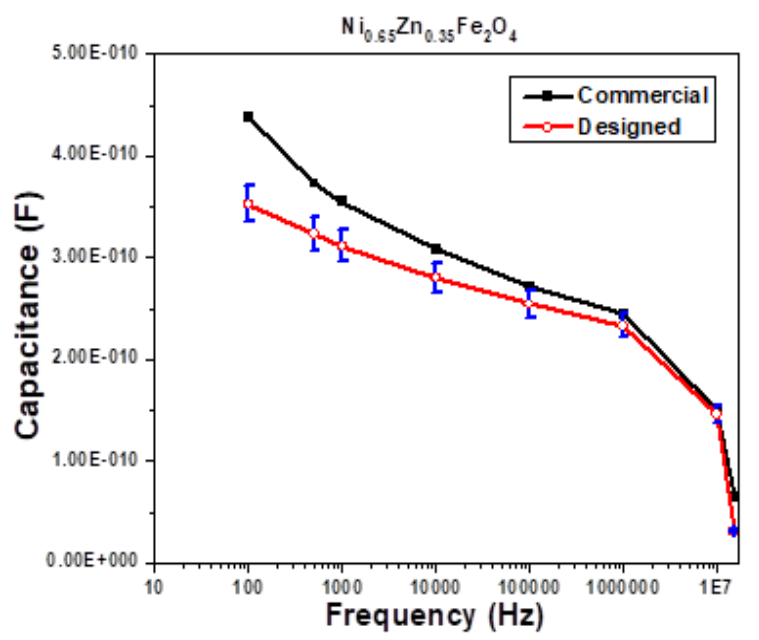

Fig. 3a. Capacitance verses Frequency plot of Ni0.65Zn0.35Fe2O4 at room temperature

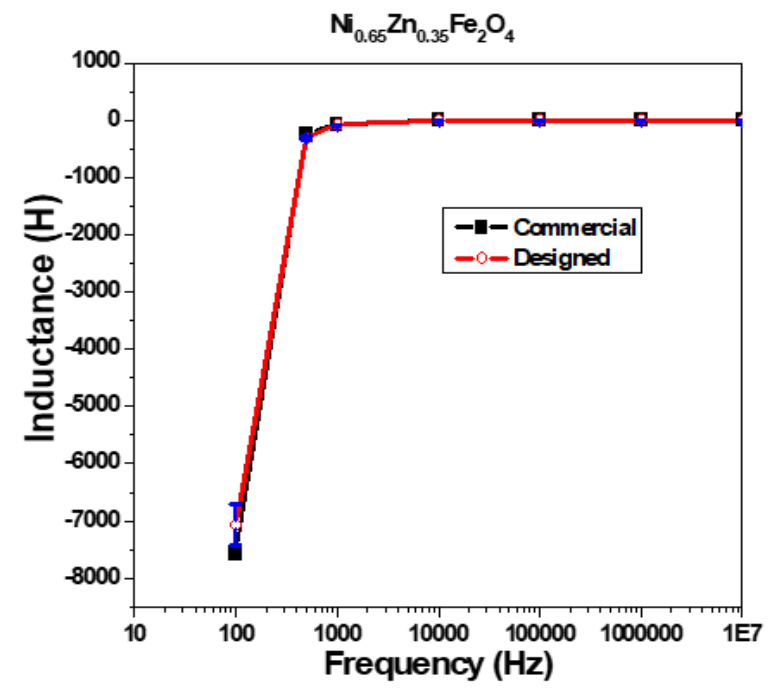

Fig. 3b. Inductance verses Frequency plot of $\mathrm{Ni0.65Zn0.35Fe2O4}$ at room temperature

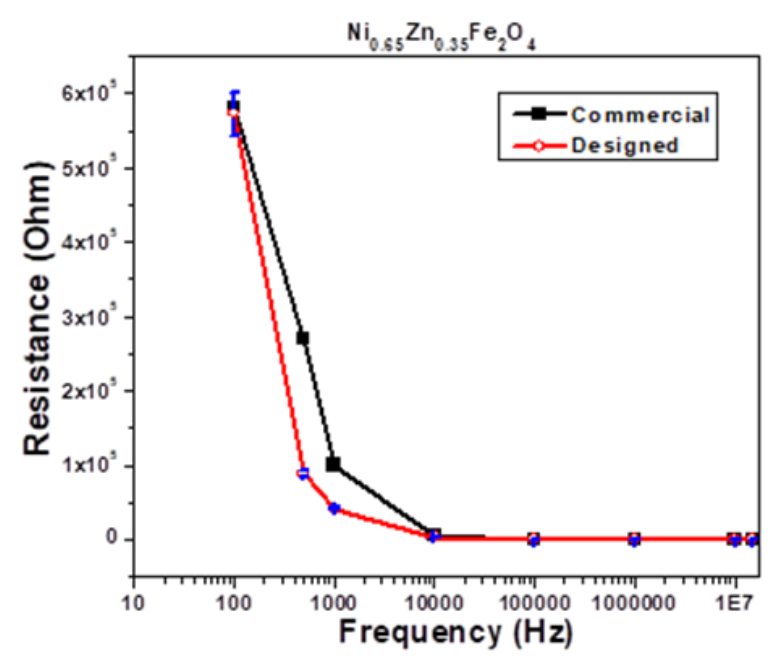

Fig. 3c. Resistance verses Frequency plot of Ni0.65Zn0.35Fe2O4 at Room-temperature

Table-III. Comparisons of Ni0.65Zn0.35Fe2O4 material at a frequency of 1 Kilo hertz

\begin{tabular}{|c|c|c|c|c|c|c|}
\hline \multicolumn{7}{|c|}{$\mathbf{N i}_{0.65} \mathbf{Z n}_{0.35} \mathbf{F e}_{2} \mathrm{O}_{4}$ at $1 \mathrm{Khz}$ frequency } \\
\hline \multirow{2}{*}{$\begin{array}{l}\text { Temperature } \\
\left({ }^{\circ} \mathrm{C}\right)\end{array}$} & \multicolumn{3}{|c|}{ Commercial Instrument Results } & \multicolumn{3}{|c|}{ Fabricated Instrument Results } \\
\hline & $\begin{array}{l}\text { Ls } \\
\text { (Henry) }\end{array}$ & $\begin{array}{l}\text { Cp } \\
\text { (Farads) }\end{array}$ & $\begin{array}{l}\text { Rs } \\
\text { (Ohms) }\end{array}$ & $\begin{array}{l}\text { Ls } \\
\text { (Henry) }\end{array}$ & $\begin{array}{l}\text { Cp } \\
\text { (Farads) }\end{array}$ & $\begin{array}{l}\text { Rs } \\
\text { (Ohms) }\end{array}$ \\
\hline 50 & $\begin{array}{l}-8.07 \mathrm{E}+0 \\
1\end{array}$ & $\begin{array}{l}3.12 \mathrm{E}-1 \\
0\end{array}$ & $\begin{array}{l}4.19 \mathrm{E}+0 \\
4\end{array}$ & $\begin{array}{l}-7.96 \mathrm{E}+0 \\
1\end{array}$ & $\begin{array}{l}3.00 \mathrm{E}-1 \\
0\end{array}$ & $\begin{array}{l}3.87 \mathrm{E}+0 \\
4\end{array}$ \\
\hline 100 & $\begin{array}{l}-7.93 \mathrm{E}+0 \\
1\end{array}$ & $\begin{array}{l}3.16 \mathrm{E}-1 \\
0\end{array}$ & $\begin{array}{l}5.06 \mathrm{E}+0 \\
4\end{array}$ & $\begin{array}{l}-7.75 \mathrm{E}+0 \\
1\end{array}$ & $\begin{array}{l}3.26 \mathrm{E}-1 \\
0\end{array}$ & $\begin{array}{l}6.04 \mathrm{E}+0 \\
4\end{array}$ \\
\hline 150 & $\begin{array}{l}-7.46 \mathrm{E}+0 \\
1\end{array}$ & $\begin{array}{l}3.29 \mathrm{E}-1 \\
0\end{array}$ & $\begin{array}{l}8.56 \mathrm{E}+0 \\
4\end{array}$ & $\begin{array}{l}-7.63 \mathrm{E}+0 \\
1\end{array}$ & $\begin{array}{l}3.32 \mathrm{E}-1 \\
0\end{array}$ & $\begin{array}{l}8.17 \mathrm{E}+0 \\
4\end{array}$ \\
\hline 200 & $\begin{array}{l}-5.08 \mathrm{E}+0 \\
1\end{array}$ & $\begin{array}{l}3.49 \mathrm{E}-1 \\
0\end{array}$ & $\begin{array}{l}2.09 \mathrm{E}+0 \\
5\end{array}$ & $\begin{array}{l}-4.96 \mathrm{E}+0 \\
1\end{array}$ & $\begin{array}{l}3.33 \mathrm{E}-1 \\
0\end{array}$ & $\begin{array}{l}2.46 \mathrm{E}+0 \\
5\end{array}$ \\
\hline 250 & $\begin{array}{l}-2.55 \mathrm{E}+0 \\
0\end{array}$ & $\begin{array}{l}3.39 \mathrm{E}-1 \\
0\end{array}$ & $\begin{array}{l}8.53 \mathrm{E}+0 \\
4\end{array}$ & $\begin{array}{l}-2.76 \mathrm{E}+0 \\
0\end{array}$ & $\begin{array}{l}3.36 \mathrm{E}-1 \\
0\end{array}$ & $\begin{array}{l}7.92 \mathrm{E}+0 \\
4\end{array}$ \\
\hline 300 & $-1.17 \mathrm{E}-01$ & $\begin{array}{l}3.40 \mathrm{E}-1 \\
0\end{array}$ & $\begin{array}{l}1.86 \mathrm{E}+0 \\
4\end{array}$ & $-1.78 \mathrm{E}-02$ & $\begin{array}{l}3.41 \mathrm{E}-1 \\
0\end{array}$ & $\begin{array}{l}2.14 \mathrm{E}+0 \\
4\end{array}$ \\
\hline 350 & $-2.46 \mathrm{E}-02$ & $\begin{array}{l}.40 \mathrm{E}-1 \\
0\end{array}$ & $\begin{array}{l}8.52 \mathrm{E}+0 \\
3\end{array}$ & $-3.43 \mathrm{E}-02$ & $\begin{array}{l}3.65 \mathrm{E}-1 \\
0\end{array}$ & $\begin{array}{l}6.92 \mathrm{E}+0 \\
3\end{array}$ \\
\hline 400 & $-8.01 E-04$ & $\begin{array}{l}4.22 \mathrm{E}-1 \\
0\end{array}$ & $\begin{array}{l}1.38 \mathrm{E}+0 \\
3\end{array}$ & $-1.60 \mathrm{E}-03$ & $\begin{array}{l}4.36 \mathrm{E}-1 \\
0\end{array}$ & $\begin{array}{l}1.02 \mathrm{E}+0 \\
4\end{array}$ \\
\hline
\end{tabular}

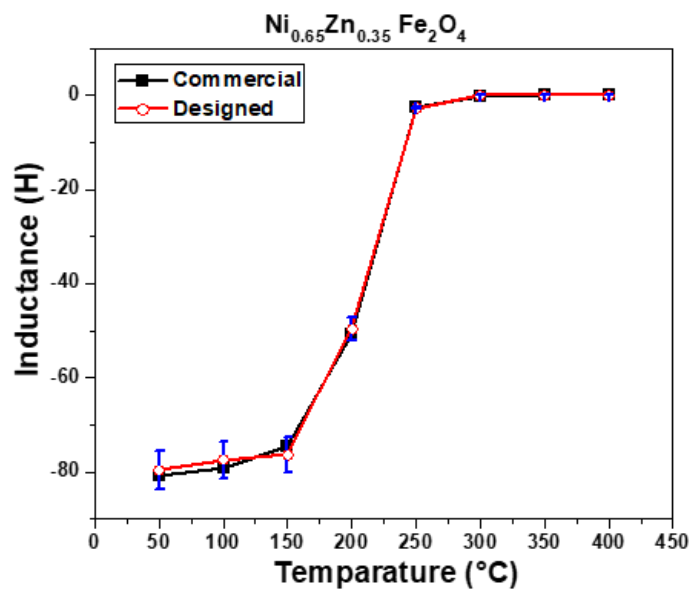

Fig. 4a. Inductance verses Temperature plot of Ni0.65Zn0.35Fe2O4 at $1 \mathrm{Khz}$ frequency

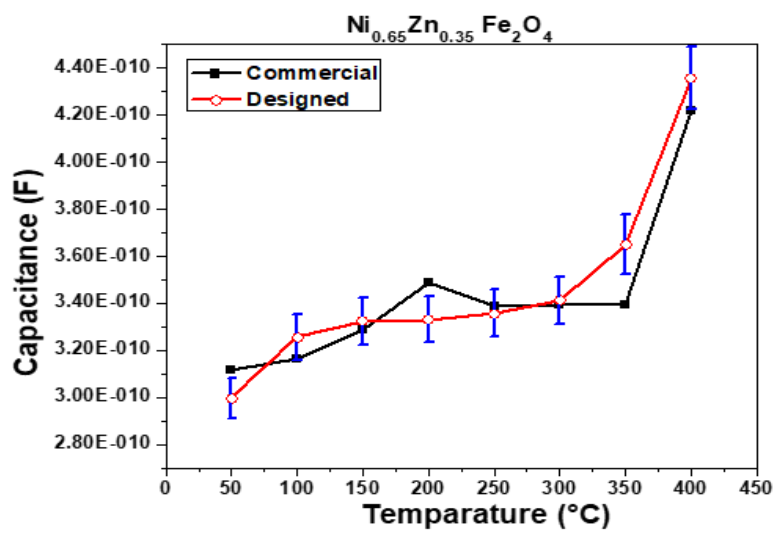

Fig. 4b. Capacitance verses Temperature plot of Ni0.65Zn0.35Fe2O4 at $1 \mathrm{Khz}$ frequency 


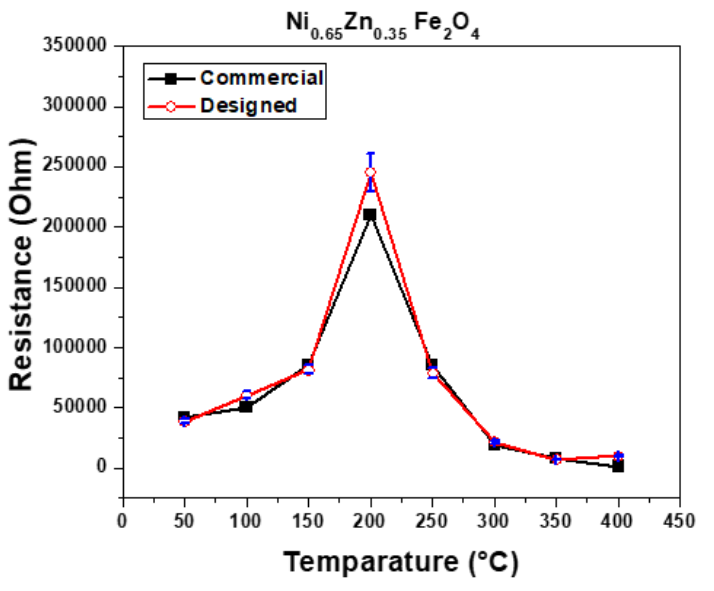

Fig. 4c. Resistance verses Temperature plot of Ni0.65Zn0.35Fe2O4 at a frequency of $1 \mathrm{Khz}$

\section{CONCLUSION}

At completion of the circuit design part and fabrication of impedance measurement meter, it's working performance is analyzed by making of measurements of electronic parameters such as $\mathrm{R}, \mathrm{Ls}$ and $\mathrm{Cp}$ by changing the signal frequency and by varying the furnace temperature up to $450^{\circ} \mathrm{C}$ for a set of composite electronic materials/components and also by correlative comparison of results generated by fabricated impedance measurement equipment with the results generated by commercially available instrument. The results obtained by both impedance measurement instruments were tabulated and graphs were plotted for all electronic materials. In all cases, it is identified that the deviations between the results obtained by both of these instruments is below $5 \%$. Thus it was concluded that the fabricated impedance measurement instrument is just deviated by $+/-3 \%$ to that of the commercial instrument. However, for the fabricated instrument, further improvements are required in terms of measuring the electrical parameters of high value components: R, L \& C of some electronic materials, further modifications are needed to deal high frequency impedance measurements.

\section{REFERENCES}

1. J. Bohacek, IEEE Trans. Instr. Meas., volume 53, No. 4, 2004, pages: 977-980

2. S. A. Awan, et al, IEEE Trans. Instr. Meas., volume 50, No. 2, 2004, pages: $282-285$

3. N. Oldham, et al, Conference Proceedings, volume 1-3 and Supplement, 1994 pages: $929-930$

4. L. Min, et al, Conference on Precision Electromagnetic Measurements Digest, 2008, pages: 574-575

5. J. Santos, et al, 18 (2) (2011) pages: $185-198$

6. H. Haruta, The impedance measurement handbook, Agilent Technologies, (2000)

7. T. Radil, et al, IEEE Trans. Instrumentation and Measurement, 57(1) (2008) pages: 197-204

8. Y. Sun, et al, Electrical Measurement \& Instrumentation 7 (2012) pages 93-96

9. G. Zhang, Electronic Measurement Technology, 37 (2014) pages: 125-129

10. Y. J. Wang, Applied Mechanics and Materials, 313 (2013) pages: $1252-1255$

11. H. Hu, Advanced Materials Research, 915 (2014) pages1 167-1170

12. http://www.newtons4th.com/wp-content/uploads/2014/08/PSM1735User-manual-v1-48.pdf

13. Davuluri Venkatesh, et al, Journal of Superconductivity and Novel Magnetism. 28 (2015) pages 2801-2807
14. P. Kanaka Raju, et al, IJARMATE. 3 (2017) pages 1-7

15. D. Joshi, D. et al, MAPAN-J. Metrol. Soc India. 24 (2009) 215-224

16. P. Kanaka Raju et al, Materials Today: Proceedings 5 (2018) pages: 25782-25788

\section{AUTHORS PROFILE}

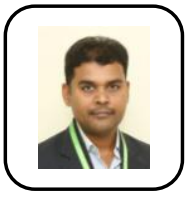

Dr. P. Kanaka Raju has received M.Sc. in Electronics from Andhra University, M.Tech from Nagarjuna University, M. phil. and PhD. degree from Andhra University. He is currently working as an Assistant Professor in GITAM Deemed to be University. His research national and International journals.

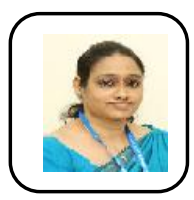

Dr. C. Kavitha has received M.Sc., M.Phil. from Andhra University, M.Tech from Nagarjuna University. She is currently working as an Associate Professor in GITAM Deemed to be University. Her research areas are Signal Processing, Embedded Systems, and Published national and International journals

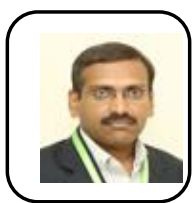

Dr. C. Mani Kumar has received his M.Sc. in Electronics from Sri Krishnadevaraya University. He is received his $\mathrm{PhD}$ degree in Sri Krishnadevaraya University. He is currently working as an Assistant Professor in GITAM University. His research areas are Embedded Systems, Biomedical Electronics and Instrumentation.

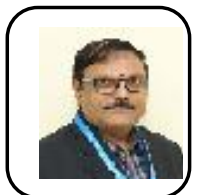

Dr. D. Rama Krishna, received M.Tech., PhD. from GITAM Deemed to be University, He is currently working as an Assistant Professor in GITAM Deemed to be University. His research areas are data mining, signal processing. Published in peer reviewed journals. 